\title{
COLIFORM INFECTION OF THE URINARY TRACT
}

BY

\author{
P. N. COLEMAN AND S. TAYLOR \\ From the Laboratory, Townleys Hospital, Bolton, Lancashire
}

(RECEIVED FOR PUBLICATION, FEBRUARY 14, 1949)

This paper concerns the investigation of the types of coliform organisms encountered in the urines of one hundred consecutive cases of pyuria admitted to Townleys Hospital, Bolton, during 1948. Recently Warner (1948), discussing urinary infection in paraplegic patients, has drawn attention to the frequency with which Bact. aerogenes was found. This organism was insensitive both to sulphanilamide and to penicillin, and Warner considered that these drugs may be of only limited value in urinary infection. It was thought that it would be interesting to discover if a similar high incidence of Bact. aerogenes would be found in other types of urinary infection and to consider all the types of coliform organisms found from the point of view of chemotherapy.

\section{Methods}

Wet and stained films of centrifuged deposits from catheter specimens of the urines were examined and the urines cultured on MacConkey's medium and blood agar. Any coliform bacilli isolated were identified by biochemical tests, and their sensitivity to sulphanilamide, penicillin, and streptomycin was determined. The fermentation reactions using glucose, mannitol, lactose, sucrose, and salicin were employed. Other tests used were: the formation of indole, gas production at $44^{\circ} \mathrm{C}$., utilization of citrate, Vosges Proskauer test (Barritt's modification), and the methyl red reaction. The coliform bacilli were identified by the criteria described in Topley and Wilson's Principles of Bacteriology and Immunity (third edition).

Of the eighteen strains of Bact. aerogenes tested, six produced gas at $44^{\circ} \mathrm{C}$. after 48 hours' incubation though not after 24 hours'. They were, however, classified as Bact. aerogenes. P. vulgaris was distinguished from $P$. morgani by the ability to swarm on blood agar. The paracolon bacilli included three anaerogenic strains, two of which were late lactose fermenters.

Sulphanilamide sensitivity tests were carried out by the method of Harper and Cawston (1945). Penicillin and streptomycin sensitivities were determined by inoculating one drop of an overnight broth culture of the organism under test into broth containing the drug in the appropriate concentration. These culturesis were incubated overnight and examined for growthu next morning.

\section{Results}

Table I shows the incidence of the varieties of coliform and other organisms associated wit various clinical conditions. The cases wero divided into two groups: group 1, in which there was no gross lesion of the urinary tract: and group 2, where infection was secondary to a surgical or medical condition affecting the tract.

It was found that in group 1 Bact. coli was the predominant organism (49 strains compared wit 12 of other organisms) whereas in group 2 Baces. coli was relatively uncommon (7 strains compared with 56 of other organisms). Its place was take in roughly equal proportions by $P$. vulgaris, $\vec{P}$. morgani, and Bact. aerogenes. In group 1 pure cultures were frequent and Gram-positive cocdi infrequent; in group 2 the reverse was found. 3 .

Table II shows the sensitivities to sulphanit; amide, penicillin, and streptomycin. In planning these tests regard was paid to the concentrations that could be obtained in the urine. The Medicall Research Council pamphlet suggests that conce tration of sulphanilamide of $100 \mathrm{mg} . / 100 \mathrm{ml}$. of urine can readily be obtained. Peeney (1946) found that concentrations of up to 200 units per ml. of penicillin could be maintained in the urine, whe Petroff and Lucas (1947) obtained average concefrtration of 70 to $100 \mu \mathrm{g}$. of streptomycin per m. Table II shows that bacteriostatic concentration to Bact. coli can be obtained in the urine both sulphanilamide and by penicillin, to $P$. vulgaris by penicillin, and to a few strains (4 out of 18) by sulphanilamide. Bacteriostatic concentratio could not be obtained with either of these troo drugs against Bact. aerogenes or P. morgani. A1 but one of the coliform strains tested were sensitife to streptomycin. 
TABLE I

VARIETIES OF COLIFORM AND OTHER ORGANISMS ASSOCIATED WITH VARIOUS CLINICAL CONDITIONS

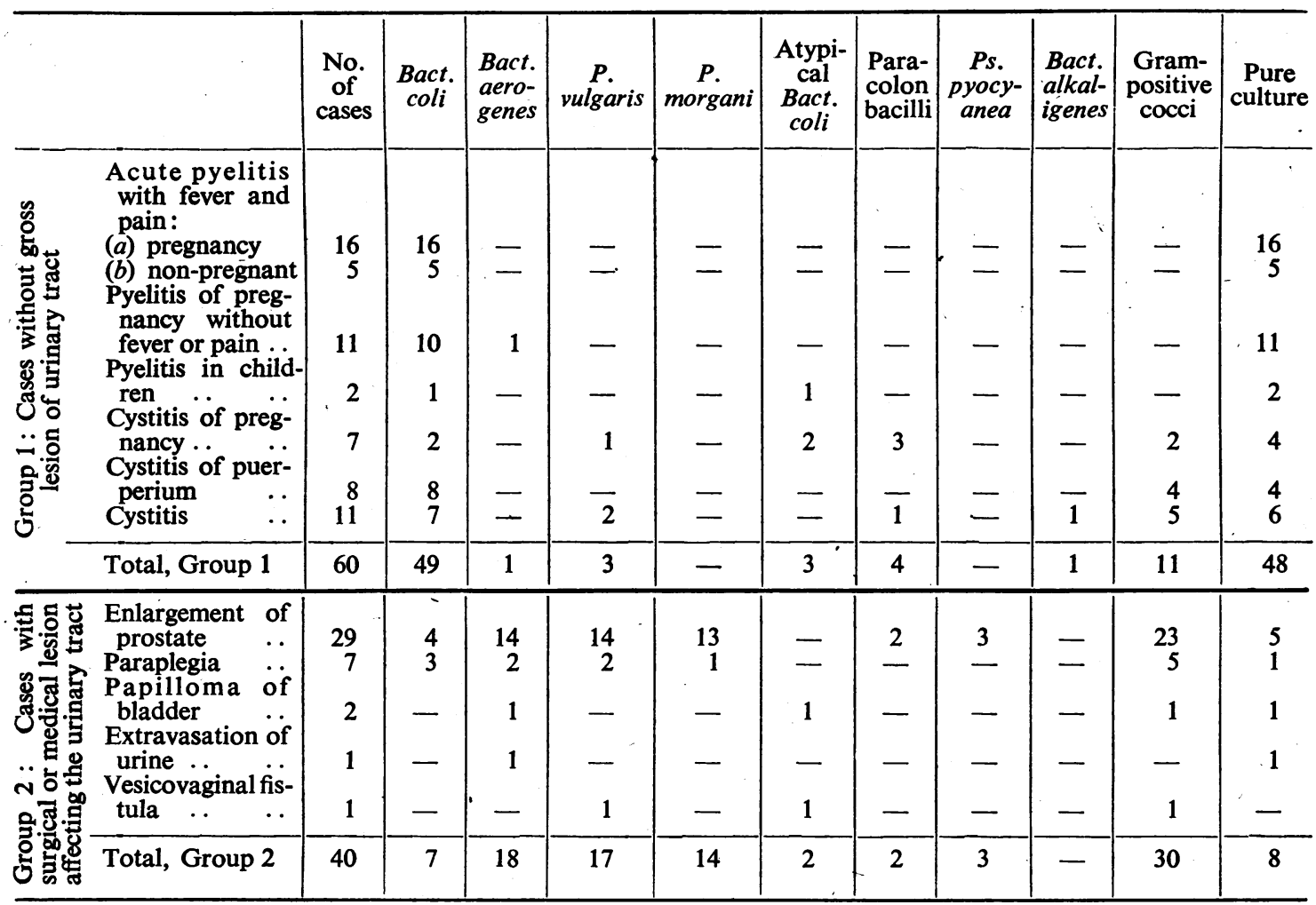

In group 2 there were two females and in group 1 three males: two young men with acute pyelitis and one child with pyelitis.

TABLE II

CONCENTRATION OF DRUG TO WHICH ORGANISMS ARE SENSITIVE

\begin{tabular}{|c|c|c|c|c|c|c|c|c|c|c|c|c|c|c|c|c|c|}
\hline & \multicolumn{4}{|c|}{ Penicillin units per ml. } & \multicolumn{5}{|c|}{ Sulphanilamide mg. per $100 \mathrm{ml}$. } & \multicolumn{8}{|c|}{ Streptomycin $\mu$ g. per ml. } \\
\hline & $\begin{array}{l}\text { No. of } \\
\text { strains } \\
\text { tested }\end{array}$ & $\begin{array}{c}\text { Not } \\
\text { sensi- } \\
\text { tive } \\
>500\end{array}$ & $\begin{array}{c}500 \\
\text { to } \\
100\end{array}$ & $\begin{array}{c}\text { Less } \\
\text { than } \\
100\end{array}$ & $\begin{array}{l}\text { No. of } \\
\text { strains } \\
\text { tested }\end{array}$ & $\begin{array}{c}\text { Not } \\
\text { sensi- } \\
\text { tive } \\
>200\end{array}$ & $\begin{array}{c}200 \\
\text { to } \\
100\end{array}$ & $\begin{array}{c}100 \\
\text { to } \\
20\end{array}$ & $\begin{array}{c}\text { Less } \\
\text { than } \\
20\end{array}$ & $\begin{array}{l}\text { No. of } \\
\text { strains } \\
\text { tested }\end{array}$ & $\begin{array}{c}1,000 \\
\text { to } \\
500\end{array}$ & $\begin{array}{c}100 \\
\text { to } \\
50\end{array}$ & $\begin{array}{l}50 \\
\text { to } \\
25\end{array}$ & $\begin{array}{l}25 \\
\text { to } \\
10\end{array}$ & $\begin{array}{c}10 \\
\text { to } \\
5\end{array}$ & $\begin{array}{c}5 \\
\text { to } \\
2.5\end{array}$ & $\begin{array}{c}\text { Less } \\
\text { than } \\
2.5\end{array}$ \\
\hline $\begin{array}{l}\text { Bact. coli } \\
\text { Bact, aero- }\end{array}$ & 56 & 1 & 2 & 53 & 56 & 1 & 2 & 22 & 31 & 27 & - & - & - & 2 & 8 & 15 & 2 \\
\hline $\begin{array}{l}\text { genes . } \\
\text { Proteus vul- }\end{array}$ & 19 & 19 & 一 & - & 19 & 17 & - & 2 & - & 12 & - & - & - & 一 & 1 & 7 & 4 \\
\hline garis & 20 & $\overline{-1}$ & - & 20 & 19 & 15 & 一 & 1 & 3 & 16 & - & 1 & 15 & - & - & - & 一 \\
\hline $\begin{array}{l}\text { P. morgani } \\
\text { Atypical }\end{array}$ & 14 & 13 & 1. & - & 12 & 11 & - & 1 & - & 10 & 1 & - & 2 & 1 & 1 & 5 & - \\
\hline $\begin{array}{l}\text { Bact. coli } \\
\text { Ps. pyo- }\end{array}$ & 5 & 1 & 2 & 2 & 5 & - & - & 4 & 1 & 4 & - & - & - & 一 & - & 4 & - \\
\hline $\begin{array}{l}\text { cyanea } \\
\text { Paracolon }\end{array}$ & 3 & 3 & - & $\therefore$ & 3 & 3 & 一 & - & - & 3 & - & - & 一 & 2 & 1 & - & - \\
\hline $\begin{array}{l}\text { bacilli } \\
\text { Bact. alkal- }\end{array}$ & 6 & 1 & 3 & 2 & 6 & - & 1 & 4 & 1 & 3 & - & - & - & 1 & - & 1 & 1 \\
\hline$i g$ & 1 & - & - & 1 & 1 & - & - & - & 1 & 1 & - & - & - & - & - & - & 1 \\
\hline
\end{tabular}

A number of sensitive organisms were tested at concentrations of penicillin $50 \mathrm{units} / \mathrm{ml}$. Out of 31 strains of Bact. coli tested 23 strains showed a good growth, 6 strains showed some inhibition, and 2 strains were completely inhibited. Out of 14 strains of $P$. vulgaris tested, 4 gave a good growth in 50 units/ml. penicillin, 8 showed some inhibition, and 2 were completely inhibited. 


\section{Discussion}

Reports vary of the incidence of the different types of coliform bacilli in urinary infections. Thus in 200 cultures from all clinical types of infection Hill et al. (1929) found 100 strains of Bact. coli, 79 strains of Bact. aerogenes, and 5 strains of the proteus group. In the urine of paraplegic patients Petroff and Lucas (1946) found $41 \%$ of the coliform organisms were Bact. aerogenes and $16 \%$ proteus, while Warner (1948), considering only those which fermented lactose, found 32 out of 50 coliform organisms studied were Bact. aerogenes. On the other hand, Cross (1937), in a series from which urinary infections secondary to prostatic enlargement were excluded, found 17 strains of Bact. coli, 2 of Bact. aerogenes, and 5 of other organisms. Marple (1941) in a series of thirteen cases of women with pyuria found Bact. coli strains only, and Dodds (1931), considering urinary infection in pregnancy, found 49 Bact. coli strains and only one Bact. aerogenes (Bact. friedlander).

The present findings suggest that the rate of urinary flow may be the factor which determines the incidence of Bact. coli in infected urines. In this series the group of cases of primary urinary infection consists largely of women and includes a high proportion of cases occurring in pregnancy, whereas the group of cases of infections secondary to obstruction includes a large proportion of cases with enlargement of the prostate. No doubt this distribution of cases is determined in part by the type of case admitted to the particular hospital, but it is thought that any representative series of cases of urinary infection would show that the primary cases were much commoner in women than in men, that in women they were often associated with pregnancy, and that the commonest cause of urinary obstruction was enlargement of the prostate (and for this reason the group where the infection was secondary to obstruction would include many cases of this condition). The series is considered, therefore, representative enough to draw general conclusions.

A possible explanation of the difference in distribution of Bact. coli infections between the two groups might be that in the first group the pyuria represents infection of kidney or bladder tissue, the urine in these cases flowing too freely to admit much bacteriological multiplication, whereas in the second group stagnation of the urine is the important factor and growth of bacteria occurs in the urine itself. As a tissue invader Bact. coli might be the most successful organism, whereas for growth in the poor medium afforded by stagnant urine the saprophytic organisms Bact. aerogene $P$. vulgaris, and $P$. morgani might have the advantage.

The results of the sensitivity tests compare witb the findings of previous papers. Bact. coli is sensitive to sulphanilamide (Strauss and Finland, 1941 M.R.C. pamphlet on sulphonamides, 1943), whif Bact. aerogenes (Warner, 1948), P. vulgaris (M.R.G. pamphlet ; Stewart, 1945), and $P$. morgani (Netef and Clark, 1944) are relatively non-sensitive. BaCP. coli and $P$. vulgaris are relatively sensitive to penis cillin (Warner, 1948 ; Stewart, 1945 ; Peeney, 1947 Bact. aerogenes and $P$. morgani are not (Warne 1948 ; Helmholz and Sung, 1944 ; Peeney, 19470 On the other hand, Warner found that the 12 Badxo coli strains tested as well as the Bact. aerogenes strains were insensitive to $50 \mathrm{mg} / 100 \mathrm{ml}$. Of sulphathiazole.

Comparing the results of the sensitivity tests with the incidence of the various types of colifor organisms investigated, success in the treatment with sulphanilamide might be expected in the non obstructive cases since Bact. coli is the commonest infecting organism, but not in the cases secondary to obstruction because coliform organisms which are not sensitive predominate in this type of infee tion. The use of penicillin might improve resulg in the cases of urinary obstruction because of its additional action on $P$. vulgaris. In the present series, however, although $\boldsymbol{P}$. vulgaris was foung in the urine of seventeen out of forty cases of infeçtion secondary to obstruction, in twelve of these cases it was accompanied by Bact. aerogenes o: $P$. morgani, organisms insensitive to penicillin. cases of urinary obstruction there is the additional factor that while the obstruction is unrelieved the is a continuing liability to reinfection; but even if this factor is disregarded the series shows the prospects for chemotherapy by sulphanilamide and penicillin are not good.

These findings are in accord with clinical expef:ence. Thus Brown (1946), discussing the treatment of the urinary infections of pregnancy with sut? phanilamide, states the results are very satisfat tory; and Donovan (1947) found that sulphots amides would not sterilize the urines of twis paraplegic patients.

Streptomycin, when it becomes available, wound seem to offer for the first time the possibility of obtaining a bacteriostatic concentration effecti花 against all types of coliform bacilli found urinary obstruction. However, the liability reinfection on withdrawal of the drug remain, and reports emphasize the rapid development of insensitive strains. Perhaps the most useful funç- 
ton of streptomycin will prove to be the obtaining of a sterile field for a limited period during which a surgical operation for relief of obstruction can be carried out.

\section{Summary}

1. The incidence of different types of coliform bacilli in cases of urinary infection has been studied. A comparison has been made between types isolated from cases of primary urinary infection and urinary obstruction. Sensitivities to sulphanilamides, penicillin, and streptomycin were determined.

2. In cases of primary urinary infection Bact. coli was the predominant organism; in cases secondary to urinary obstruction Bact. aerogenes, $P$. vulgaris, and $P$. morgani predominated.

3. Bact. coli is sensitive to sulphanilamide and penicillin in concentration obtainable in urine. $P$. vulgaris is sensitive to penicillin, but $P$. morgani and Bact aerogenes are sensitive to neither of these drugs. All types of coliform bacilli tested are sensitive to streptomycin.
4. Because of the high incidence of non-sensitive strains found in cases of urinary infection secondary to obstruction, no benefit from treatment with sulphonamides or penicillin is likely.

We should like to thank Dr. Doris Stone for advice and criticism and for carrying out the Eijkman tests, and Drs. E. S. Gawne and L. A. Ledingham for help in the clinical diagnosis of the cases quoted.

\section{REFERENCES}

Brown, F. J. (1946). Ante Natal and Post Natal Care (6th Ed.),

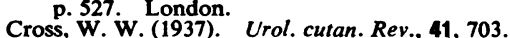

Dodds, G. H. (1931). J. Obstet. Gynaec. Brit. Emp., 38, 773.

Donovan, H. (1947). Lancet, 1, 515

Harper, G. J., and Cawston, W. C. (1945). J. Path. Bact., $57,59$.

Helmholz, H. F., and Sung, C. (1944). Amer. J. Dis. Child. 68, 236

Hill, J. H., Seidman, L. R., Stadnichenko, A. M. S., and Ellis, M. G. (1929). J. Bact., 17, 205.

Marple, C. D. (1941). Ann. int. Med., 14, 2220.

"Medical Use of Sulphonamides" (1943). Med. Res. Coun. Lond. War. Mem., No. 10 .

Neter, E. R., and Clark, P. (1944). Proc. Soc. exp. Biol., N.Y., 66, 34. Peeney, A. L. P. (1947). Proc. R. Soc. Med., 40, 433.

Petroff, B. P., and Lucas, F. V. (1946). Ann. Surg., 123, 808.

Stewart, G. T. (1945). Lancet, 2, 705.

Strauss, E.. and Finland, M. (194i). Proc. Soc. exp. Biol. N.Y., 47, 432

Warner, P. T. J. C. P. (1948). Brit. med. J., i, 146.

Wilson, G. S., and Miles, A. A. (1946)., "Topley and Wilson's Principles of Bacteriology and Immunity " (3rd Ed.). Arnold, London. 